\title{
Spatial Long-Term Memory Retention by Banana and Papaya Peel Extract: In silico and in vivo Evaluation
}

\author{
Kanala Somasekhar Reddy, Pamisetty Likithasree, Ramlingam Peraman, Mallela Vijaya Jyothi, Chilamakuru Naresh Babu, Bhupalam \\ Pradeepkumar, Akkiraju Sudheer* \\ Department of Pharmacology, Department of Pharmaceutical Chemistry, Raghavendra Institute of Pharmaceutical Education and Research (RIPER), Ananthapuramu, \\ Andhra Pradesh, INDIA.
}

\begin{abstract}
Objectives: Alzheimer's disease is a leading neurodegenerative disorders having serious effect on an individual's occupational potential and quality of life. The natural and nutritional based remedy is continuing interest for neurological disorders; hence an attempt was made to reveal memory enhancing potential of commonly available fruits, by applying the molecular docking studies. Methods: The study was conducted in aluminium chloride induced Alzheimer's Wistar albino rats for the period of 28 days. The oral administered animal groups with ethanolic extracts of peels of ripped banana and papaya (200 and $400 \mathrm{mg} / \mathrm{kg}, \mathrm{p} .0$ ) is comparatively evaluated with positive control rats (donepezil, $1 \mathrm{mg} / \mathrm{kg}$. p.o) by behavioural studies like pole climbing test and elevated plus maze test, biochemical and histopathological parameters. Further, interaction of selected leads of banana and papaya peel with selected targets were analysed by Schrodinger Glide software. Results: Memory enhancing effects of peels was supported by shortening of transfer latency (elevated plus maze), increased number of escapes (cooks pole climbing), enhancement of brain tissue antioxidant defensive enzymes such as SOD, Catalase, $\mathrm{GSH}$, reduction of activity of acetylcholine esterase and improvement of
\end{abstract}

histopathological changes. Memory enhancement effect further observed by best docking score and glide energy of selected leads with targets of Alzheimer's disease such as beta secretase and acetylcholine esterase. Conclusion: On the basis of the present study, the results revealed that peel extracts of papaya and banana and used as adjuvant which shows anti-Alzheimer's disease.

Key words: Banana and papaya peel extract, Antioxidant activity, Spatial long-term memory enhancement, Aluminium chloride induced memory loss.

\section{Correspondence}

Akkiraju Sudheer

Department of Pharmacology, Department of Pharmaceutical ChemistryRaghavendra Institute of Pharmaceutical Education and Research (RIPER), Ananthapuramu-515721, Andhra Pradesh, INDIA.

Phone no: +918985544288

Email: sudeerlegend@gmail.com

DOI: 10.5530/ijpi.2020.2.37

\section{INTRODUCTION}

Alzheimer's disease $(\mathrm{AD})$ is an irreversible, progressive brain neurodegenerative disorder characterized by memory loss and is accounted for about 80 percent of dementia cases. As per National Institute of Health $(\mathrm{NIH})$, the prevalence of $\mathrm{AD}$ indicated that the disorder is at third place for causing death in older people, immediately next to cardiovascular disease and cancer. ${ }^{1}$ Actually, the number of AD patients escalate double for every 20 years and expected to pile up 74.7 and 131.5 million as with 2030 and 2050 respectively. ${ }^{2}$ Despite the available drugs and research reports on discovery of successful neuroprotective agents in literature, the search for low toxic and efficacious drugs is still major concern among neurologists. ${ }^{3}$ As per literature, one best way to antagonize the neurodegeneration and to increase the scavenging of free radicals is treatment with antioxidant-rich supplements, especially from natural origin. ${ }^{4}$ In accordance to the above statement, the phytochemicals like flavonoids, polyphenols, steroids and other antioxidants have been proven as potent neuroprotective agents for their ability to reduce amyloid formation and for targeting cholinergic deficits. ${ }^{5}$ Hence, it was our enthusiasm to investigate the peels of abundantly available fruits for memory enhancement potential using in vivo experiments. This work was designed to investigate the memory enhancing effect of peels of banana and papaya using behavioral and biochemical studies in $\mathrm{AlCl}_{3}$ induced Alzheimer's disease Wistar rats.

\section{MATERIALS AND METHODS}

Preparation of ethanolic Banana peel (EBP) and ethanolic Papaya peel (EPP) extracts.

About $500 \mathrm{~g}$ of each, dried peel powders of banana and papaya macerated with ethanol (99.9\%). Finally, concentrated semi-solid mass of extracts was stored in airtight amber coloured glass bottle at $4^{\circ} \mathrm{C}$, until further use. $^{6}$

\section{Qualitative Phytochemical evaluation}

The diluted solutions $(1 \mathrm{mg} / \mathrm{ml})$, ethanolic extracts of banana (EBP) and papaya (EPP) were subjected for various preliminary qualitative phytochemical tests as per reported procedure.?

\section{Thin Layer Chromatography}

The diluted peel extracts (EBP and EPP) were spotted on silica gel precoated TLC plates in triplicate and were developed using mobile phase consisted of chloroform and methanol $(96: 4 \% v / v)$. The retardation factor $\left(\mathrm{R}_{f}\right)$ values for respective spots are reported in Table 1 .

\section{Estimation of total phenolic content}

Total phenolic content and flavonoid contents were estimated by FolinCiocalteu and aluminium chloride reagent mentioned in literature. The contents were as milligrams of Gallic acid equivalents (GAE) and 
Quercetin equivalents (QE) per gram of dry mass (mg GAE/g DW) reported in Table 1.

\section{In vitro antioxidant activity}

DPPH radical scavenging activity of both peel extracts were determined by previously reported methods and its $\mathrm{IC}_{50}$ values noted from the absorbance versus concentration plot of standard. ${ }^{8}$

\section{In silico molecular docking studies}

The chemical constituents of Banana peel extract - Delphinidin, Quercetin, Gallocatechin and Cyanidin and Papaya peel extract - Rutin, Gallic acid, Caffeic acid, Isorhamnetin and Ferulic acid were docked against Structure of Beta-Secretase (Code: 1FKN) and Acetylcholinesterase (Code: 1QTI) using Schrodinger Glide software (Version).

\section{Docking procedure}

\section{Ligand Preparation}

The extracted chemical constituents of Banana peel and Papaya peel 2D structures were downloaded from Pubchem online data base in SDF format. Then Click on Ligprep, select all ligands and required parameters (Ionization, chirality etc) were selected. After selecting click on out, in working directory file was created.

\section{Macromolecule (Protein) preparation}

The protein structure codes (1FKN and 1QTI) from protein data bank (PDB) online data base was entered in protein preparation wizard, then clicked pre-process - selected one chain (If it is unique to other chains), in review and modify kept co-crystal ligand and removed remaining all ligands. Then in refine, first protein was optimized, then water molecules are removed and it is minimized.

\section{Grid Preparation}

In maestro search, select receptor grid generation - generated grid suitable for peptide docking by selecting the ligand molecule on screen, it shows grid box. In case of $1 \mathrm{FKN}$ there is no co-crystal ligand, the grid box is generated by using sitemap the remaining options - site, constraints and Rotatable groups were enabled according to the requirements and click run.

\section{Ligand docking}

Glide grid and ligand outmaegz zip files were selected. In settings write XP descriptor information is selected and clicked on run. The docking score and glide energy were shown in (Table 1) and the docking pose of each constituent of the extract with amino acid residues were represented. ${ }^{9}$

\section{Pharmacological Screening}

\section{Acute toxicity Studies}

The oral acute toxicity study was performed as per OECD guidelines 423. No toxic effects and no significant changes in behavioral parameters were observed at a single dose of $2000 \mathrm{mg} / \mathrm{kg} .{ }^{10}$

\section{Treatment schedule}

Animal experimentations were carried after with approved protocol (Approval no. IAEC/XI/07/RIPER/2018 dated 17/02/2018. A total of 42 rats were randomly divided into 7 groups (Group I to VII) and each group consists of 6 animals $(n=5)$.

\begin{tabular}{|c|c|c|}
\hline $\begin{array}{c}\text { Group } \\
\text { I }\end{array}$ & normal control & received vehicle only \\
\hline $\begin{array}{c}\text { Group } \\
\text { II }\end{array}$ & $\begin{array}{c}\text { Disease control (negative } \\
\text { control) }\end{array}$ & received $\mathrm{AlCl}_{3}(100 \mathrm{mg} / \mathrm{kg}$ p.o $)$ \\
\hline $\begin{array}{c}\text { Group } \\
\text { III }\end{array}$ & $\begin{array}{c}\text { Positive control (standard) } \\
\text { donepezil }(1 \mathrm{mg} / \mathrm{kg}, \text { p.o }) \text { along } \\
\text { with } \mathrm{AlCl}_{3}\end{array}$ \\
\hline $\begin{array}{c}\text { Group } \\
\text { IV }\end{array}$ & $\begin{array}{c}\text { Test animal group (EBP- } \\
200)\end{array}$ & $200 \mathrm{mg} / \mathrm{kg}$, p.o along with $\mathrm{AlCl}_{3}$ \\
\hline $\begin{array}{c}\text { Group } \\
\text { V }\end{array}$ & $\begin{array}{c}\text { Test animal group (EBP- } \\
400)\end{array}$ & $400 \mathrm{mg} / \mathrm{kg}$, p.o along with $\mathrm{AlCl}_{3}$ \\
\hline $\begin{array}{c}\text { Group } \\
\text { VI }\end{array}$ & $\begin{array}{c}\text { Test animal group (EPP- } \\
200)\end{array}$ & $200 \mathrm{mg} / \mathrm{kg}$, p.o along with $\mathrm{AlCl}_{3}$ \\
\hline $\begin{array}{c}\text { Group } \\
\text { VII }\end{array}$ & $\begin{array}{c}\text { Test animal group (EPP- } \\
400)\end{array}$ & $400 \mathrm{mg} / \mathrm{kg}$, p.o along with $\mathrm{AlCl}_{3}$ \\
\hline
\end{tabular}

At pre-determined intervals such as at 1 st, $15^{\text {th }}$ and $28^{\text {th }}$ day, all groups were tested for behavioural parameters using pole climbing test and elevated plus maze test. ${ }^{11}$

\section{Evaluation of behavioural parameters}

\section{a) Elevated plus-maze test for spatial memory in rats}

The Elevated plus-maze (EPM) analysis is the model used for measuring long-term memory. Animals with short the transfer latency time indicates that the animal to learn and memory retention ability. While experimentation, note down the time required for the animal to enter any one of the closed arm from the end of the open arm. ${ }^{12}$

\section{b) Pole climb response test in Rats}

Conditioned avoidance response is to assess the nootropic and neuroprotective effect of medicinal agents by using Pole climb response apparatus. On the day of testing, numbers of escapes were noted per 20 trials. $^{13}$

\section{Estimation of biochemical parameters}

On $29^{\text {th }}$ day, the brain homogenate was obtained as per reported procedure and subjected for the estimations of various biochemical parameters which included superoxide dismutase (SOD), Catalase (CAT), reduced glutathione, lipid peroxidation and acetyl choline esterase activity. ${ }^{14}$

\section{Histopathology}

The spared part of the brain tissue immediately fixed with $10 \%$ formalin. Thereafter, the specimens were embedded in paraffin, sectioned at $5 \mu \mathrm{m}$ and stained with hematoxylin and eosin.

\section{Statistical Analysis}

The analysis of data was done by using one-way analysis of variance (ANOVA), followed by Tukey's multiple comparison tests by using Graph pad prism 5.0 software (Graph pad, Sandiego, CA).

\section{RESULTS}

Physical appearance: The obtained extract of ethanolic extract of banana and papaya peel extract observed physically and reported in the (Table 1).

Preliminary qualitative phytochemical screening: Presence of bioactive phytochemicals such as flavonoids, isoflavonoids, tannins in the extract exhibit good anti-Alzheimer's activity through neuroprotective and antiamnesic effect in various in vivo studies. Reported in the (Table 1). 
Thin Layer Chromatography: TLC analysis to confirm the presence of flavonoids. Both extracts run TLC with a solvent system of chloroform: Methanol (96:4) and find the $\mathrm{R}_{f}$ values of yellow spotted dots. Yellow appearance with iodine vapour and $\mathrm{R}_{f}$ values of extract matched with standard flavanoids (Quercetin) indicate appropriately that both extracts have confirmation with quercetin type flavonoids. $\mathrm{R}_{f}$ values are noted in (Table 1).

Estimation of Total phenolic and flavonoid content: Both extracts have a considerable amount of phenolic and flavonoid content and papaya peel extract observed with a high amount of phenolic and flavonoid content compared to banana peel extract. The results were noted in the (Table 1 ). The results were expressed as mg of gallic acid equivalents per $g$ of extract calculated from a standard curve of Gallic acid $(20-100 \mathrm{mg} / \mathrm{ml}$, $\left.y=0.0004 x+0.0083, R^{2}=0.9957\right)$. The total flavonoid content estimated by aluminum chloride method and results were expressed as $\mathrm{mg}$ of Quercetin equivalents per g of extract calculated from a standard curve of quercetin (20-100 mg/ml, y=0.0001x+0.0072, $\left.\mathrm{R}^{2}=0.9945\right)$.

In vitro antioxidant activity: The intensity of solution color decreases in the presence of anti-oxidative plant extract. $\mathrm{DPPH}$ receive electron or hydrogen radical from antioxidative bioactive compounds in the extract thereby form colorless diamagnetic molecule which shows less absorption. The degree of the potency of Antioxidant activity of plant extracts indirectly proportional to absorption and its results noted in the (Table 1).

\section{Behavioural parameters}

Treatment of animals with both peel extract (banana and papaya) exhibited the significant shorten the transfer latency time as well as increase the number of avoidance compared to aluminum treated animal in a dose-dependent manner. Noted in the (Table 2).

Estimation of biochemical parameters: Treated with both peel extract restores the levels of SOD, CAT, GSH and decreased MDA in rat brain compared with $\mathrm{AlCl}_{3}$ treated rats. This correlated with the antioxidant activity of peel extract. The balance of reactive oxygen species and defensive factors by natural agents could be proved as better antidementia agents. Reported in the (Table 3).

Docking details of major leads of Banana and Papaya Peel Extract with target proteins

1. Delphinidin (component of banana peel extract): A binding pose of Delphinidin with Beta-Secretase (Chain A; PDB gene code: 1FKN). The pink coloured lines indicate H-bonding of hydroxyl groups with amino acid residues PHE108, GLY34, THR72 and THR231. The pinkish blue coloured line indicates positive-positive interaction oxygen with amino acid residue ASP228. A binding pose of Delphinidin with Acetylcholinesterase (Chain A; PDB gene code: 1QTI). The pink coloured lines indicate $\mathrm{H}$-bonding of hydroxyl groups with amino acid residues PHE331 and ASP72. The green coloured lines indicate hydrophobic interactions with amino acid residues TRP84 and PHE330.

2. Rutin (component of papaya peel extract): A binding pose of Rutin with Beta-Secretase (Chain A; PDB gene code: 1FKN). The pink coloured lines indicate H-bonding of hydroxyl groups with amino acid residues TYR71, ARG128, ILE126 and THR231. The green coloured line indicates hydrophobic interactions with amino acid residue ARG128.A binding pose of Rutin with Acetylcholinesterase (Chain A; PDB gene code: 1QTI). The pink coloured lines indicate H-bonding of hydroxyl groups with amino acid residues GLH199, TYR334, TYR121, TYR70 and ASP72. The green coloured lines indicate hydrophobic interactions with amino acid residues TRP84 and TYR121. Insilico analysis of are reported in the (Table 4 and Figure 1).

\section{Histopathology of hippocampus}

Aluminium chloride administered rat histoarchitecture of hippocampus showed with shiny white plaques over pyramidal layer and also observed the loss of pyramidal layer is the indication of neurodegeration, the above histopathological changes are considerably decreased by both peel extract (banana and papaya). Which information came to know that both peel extract may have neuroprotective. Histopathological changes observed in Figure 2.

\section{DISCUSSION}

Presence of bioactive phytochemicals' such as flavonoids, isoflavonoids, tannins in the extract exhibit good anti-Alzheimer's activity through neuroprotective and anti-amnesic effect in various invivo studies. ${ }^{15}$ The positive qualitative analysis for secondary metabolites includes flavonoids, alkaloids, saponins, tannins, glycosides and steroids gives a basis for including extracts (banana and Peel extract) in the research work. Both extracts have a considerable amount of phenolic and flavonoid content, which is correlated with DPPH free radical neutralizing effect. ${ }^{16}$ Literature suggested major bioactive leads of Banana and papaya peel exhibited showed better docking score towards important targets of Alzheimer's disease such as Beta-secretase (1FKN) and Acetylcholinesterase (1QTI)

Table 1: Qualitative and Quantitative phyto-chemical screening of ethanolic extracts of peels of Banana and papaya.

\begin{tabular}{|c|c|c|c|}
\hline $\begin{array}{l}\text { S. } \\
\text { NO }\end{array}$ & Parameters & EBP & EPP \\
\hline 1 & Extraction process & $\begin{array}{l}\text { Maceration } \\
\text { (Ethanol ) }\end{array}$ & $\begin{array}{c}\text { Maceration } \\
\text { (Ethanol) }\end{array}$ \\
\hline 2 & Quantity of peels & $500 \mathrm{~g}$ & $500 \mathrm{~g}$ \\
\hline 3 & Extractive value & $8 \%$ & $10 \%$ \\
\hline \multirow[t]{13}{*}{4} & Qualitative test & & \\
\hline & Alkaloids & + & ++ \\
\hline & Flavanoids & +++ & +++ \\
\hline & Glycosides & + & ++ \\
\hline & Phenols & + & ++ \\
\hline & Saponins & + & ++ \\
\hline & Tannins & + & + \\
\hline & Terpenes & - & - \\
\hline & Steroids & + & + \\
\hline & Carbohydrates & + & + \\
\hline & Proteins & + & + \\
\hline & Amino acids & + & + \\
\hline & Fats and Oils & ++ & ++ \\
\hline \multirow[t]{3}{*}{5.} & Quantitative analysis & & \\
\hline & $\begin{array}{c}\text { \% Total Phenols (mg of } \\
\text { GAE/g) }\end{array}$ & $28 \pm 2.887$ & $36.33 \pm 1.667$ \\
\hline & $\begin{array}{c}\% \text { Total Flavanoids (mg } \\
\text { of QE/g) }\end{array}$ & $39.25 \pm 2.887$ & $51.75 \pm 2.887$ \\
\hline \multirow[t]{3}{*}{6.} & TLC Profile & & \\
\hline & Number of spots & & \\
\hline & $\mathrm{R}_{f}$ (flavanoids) & 0.75 & 0.68 \\
\hline \multirow[t]{2}{*}{7.} & Antioxidant activity & & \\
\hline & $\begin{array}{c}\operatorname{DPPH~EC}_{50} \text { values }(\mu \mathrm{g} / \\
\mathrm{ml})\end{array}$ & $140.45 \pm 1.95$ & $107.62 \pm 4.92$ \\
\hline
\end{tabular}


Table 2: Screening of ethanolic extract of Peels of Banana and papaya for memory enhancing potential in Alzheimer's induced rats.

\begin{tabular}{|c|c|c|c|c|c|c|}
\hline \multirow{3}{*}{ Groups $(n=6)$} & \multicolumn{6}{|c|}{ Specific Behavioural models related to memory (Rats) } \\
\hline & \multicolumn{3}{|c|}{ Elevated plus maze test Transfer Latency (in sec) } & \multicolumn{3}{|c|}{ Cooks Pole climbing (No. of escapes per 20 trials) } \\
\hline & 1 Day & 15 Day & 28 Day & 1 Day & 15 Day & 28 Day \\
\hline $\begin{array}{l}\text { Control } \\
\text { NSW }\end{array}$ & $28.47 \pm 1.09$ & $25.87 \pm 1.1^{7} b$ & $5.33 \pm 0.35 \mathrm{~d}$ & $8.66 \pm 0.88$ & $17.16 \pm 0.40 \mathrm{~d}$ & $18.00 \pm 0.44 \mathrm{~b}$ \\
\hline $\begin{array}{c}\mathrm{AlCl}_{3} \\
100 \mathrm{mg} / \mathrm{kg}\end{array}$ & $35.66 \pm 044$ & $43.80 \pm 1.7^{4} \mathrm{~d}$ & $46.06 \pm 1.0^{1} \mathrm{~d}$ & $9.83 \pm 0.63$ & $5.83 \pm 0.54^{\mathrm{c}}$ & $7.83 \pm 0.60^{\mathrm{C}}$ \\
\hline $\begin{array}{c}\text { DZPL } \\
1 \mathrm{mg} / \mathrm{kg}\end{array}$ & $35.93 \pm 0.92$ & $32.67 \pm 0.7^{6} \mathrm{~d}$ & $28.21 \pm 0.7^{6} \mathrm{~d}$ & $8.50 \pm 1.90$ & $14.66 \pm 0.66^{\mathrm{c}}$ & $16.00 \pm 0.73^{c}$ \\
\hline $\mathrm{EBP}-200 \mathrm{mg} / \mathrm{kg}$ & $35.26 \pm 0.81$ & $32.93 \pm 0.7^{7} b$ & $30.13 \pm 1.5^{1}$ a & $9.66 \pm 1.45$ & $10.00 \pm 1.53^{\mathrm{a}}$ & $13.16 \pm 1.64^{b}$ \\
\hline $\begin{array}{l}\text { EBP-400 } \\
\mathrm{mg} / \mathrm{kg}\end{array}$ & $35.47 \pm 70$ & $38.40 \pm 1.0^{1} \mathrm{c}$ & $40.10 \pm 0.4^{7} c$ & $10.00 \pm 0.68$ & $11.00 \pm 0.85^{\mathrm{b}}$ & $15.16 \pm 0.75^{b}$ \\
\hline $\begin{array}{l}\text { EPP-200 } \\
\mathrm{mg} / \mathrm{kg}\end{array}$ & $36.13 \pm 0.53$ & $39.20 \pm 0 .{ }^{9} 2 \mathrm{a}$ & $40.93 \pm 1.0^{8} \mathrm{~b}$ & $10.33 \pm 1.08$ & $11.16 \pm 1.74^{b}$ & $13.66 \pm 1.73 \mathrm{~b}$ \\
\hline $\begin{array}{c}\text { EPP-400 } \\
\mathrm{mg} / \mathrm{kg}\end{array}$ & $35.73 \pm 0.51$ & $38.82 \pm 0 .^{5} \mathrm{c}$ & $40.60 \pm 0.9^{3} c$ & $10.33 \pm 0.80$ & $14.33 \pm 1.41^{\mathrm{c}}$ & $16.33 \pm 0.42^{\mathrm{C}}$ \\
\hline
\end{tabular}

Values are expressed as mean $\pm \operatorname{SEM}(n=6) ; p<0.05$ indicated by letter a; $p<0.01$ indicated by $\mathrm{b} ; p<0.001$ indicated by letter $\mathrm{c}$ and $p<0.0001$ indicated by letter without letter indicate the non-significant.

Table 3: Effect of ethanolic extract of Peels of Banana and papaya for Tissue Markers.

\begin{tabular}{|c|c|c|c|c|c|}
\hline \multirow{3}{*}{ Groups $(n=6)$} & \multicolumn{5}{|c|}{ Biochemical parameters rat brain tissue } \\
\hline & \multicolumn{4}{|c|}{ Antioxidant Defensive system } & \multirow{2}{*}{$\begin{array}{c}\text { Mechanistic model } \\
\text { Acetylcholinesterase activity } \\
(\mu \mathrm{mol} / \mathrm{min} / \mathrm{mg} \text { of protein) }\end{array}$} \\
\hline & SOD (U/mg wet tissue) & $\begin{array}{l}\text { CAT ( } \mu \text { mole } \mathrm{H} 2 \mathrm{O} 2 \\
\text { decomposed } / \mathrm{mg} \text { wet } \\
\text { tissue) }\end{array}$ & $\begin{array}{c}\text { GSH (nmol GSH/mg } \\
\text { wet tissue) }\end{array}$ & $\begin{array}{l}\text { LPO (nmol MDA/mg } \\
\text { wet tissue) }\end{array}$ & \\
\hline $\begin{array}{l}\text { Control } \\
\text { NSW }\end{array}$ & $29.17 \pm 0.40$ & $48.14 \pm 1.089$ & $51.98 \pm 1.8$ & $66.59 \pm 1.45$ & $13.62 \pm 1.07$ \\
\hline $\begin{array}{c}\text { DZPL } \\
1 \mathrm{mg} / \mathrm{kg}\end{array}$ & $29 \pm 0.83^{\mathrm{d}}$ & $46.85 \pm 1.43^{\mathrm{C}}$ & $52.67 \pm 2.50^{\mathrm{d}}$ & $62.62 \pm 1.66^{\mathrm{C}}$ & $15.14 \pm 1.39^{c}$ \\
\hline $\begin{array}{l}\text { EBP-200 mg/ } \\
\mathrm{kg}\end{array}$ & $23.54 \pm 0.80^{b}$ & $44.15 \pm 0.64^{\mathrm{b}}$ & $45.84 \pm 0.27^{\mathrm{a}}$ & $63.6 \pm 2.07^{c}$ & $22.37 \pm 1.56$ \\
\hline $\begin{array}{c}\mathrm{EPP}-200 \\
\mathrm{mg} / \mathrm{kg}\end{array}$ & $23.51 \pm 0.43^{b}$ & $45.64 \pm 1.70^{\mathrm{C}}$ & $45.86 \pm 1.05^{\mathrm{a}}$ & $65.76 \pm 2.00^{\mathrm{c}}$ & $18.18 \pm 0.98^{\mathrm{a}}$ \\
\hline $\begin{array}{c}\mathrm{EPP}-400 \\
\mathrm{mg} / \mathrm{kg}\end{array}$ & $24.22 \pm 0.52^{\mathrm{b}}$ & $46.47 \pm 1.28^{\mathrm{C}}$ & $46.12 \pm 3.87^{\mathrm{a}}$ & $68.86 \pm 0.51^{b}$ & $16.60 \pm 1.55^{\mathrm{b}}$ \\
\hline
\end{tabular}

Values are expressed as mean $\pm \operatorname{SEM}(n=6) ; p<0.05$ indicated by letter a; $p<0.01$ indicated by $b ; p<0.001$ indicated by letter $\mathrm{c}$ and $p<0.0001$ indicated by letter without letter indicate the non-significant. 
Table 4: Docking score and Glide energy of chemical constituents of Banana peel extract and Papaya peel extract with Beta-secretase (1FKN) and Acetylcholinesterase (1QTI).

\begin{tabular}{|c|c|c|c|c|c|}
\hline S. No & Chemical constituent & $\begin{array}{c}\text { Docking Score } \\
\text { (Kcal/mol) }\end{array}$ & $\begin{array}{l}\text { Glide Energy } \\
\text { (Kcal/mol) }\end{array}$ & $\begin{array}{l}\text { Docking Score } \\
\text { (Kcal/mol) }\end{array}$ & $\begin{array}{l}\text { Glide Energy } \\
\text { (Kcal/mol) }\end{array}$ \\
\hline \multicolumn{2}{|r|}{ Banana Peel Extract } & \multicolumn{2}{|c|}{$1 F K N$} & \multicolumn{2}{|c|}{ 1QTI } \\
\hline 1 & Delphinidin & -8.419 & -46.238 & -12.636 & -43.788 \\
\hline 2 & Quercetin & -7.45 & -42.683 & -10.644 & -49.32 \\
\hline 3 & Gallocatechin & -7.143 & -35.73 & -11.296 & -50.625 \\
\hline 4 & Cyanidin & -7.102 & -43.426 & -10.725 & -45.967 \\
\hline \multicolumn{6}{|c|}{ Papaya Peel Extract } \\
\hline 1 & Rutin & -9.744 & -60.613 & -14.17 & -66.418 \\
\hline 2 & Gallic acid & -7.025 & -33.163 & -7.385 & -34.41 \\
\hline 3 & Caffeic acid & -6.953 & -31.617 & -7.19 & -32.102 \\
\hline 4 & Isorhamnetin & -6.773 & -41.34 & -10.166 & -40.409 \\
\hline 5 & Ferulic acid & -5.793 & -29.022 & -6.548 & -37.611 \\
\hline
\end{tabular}
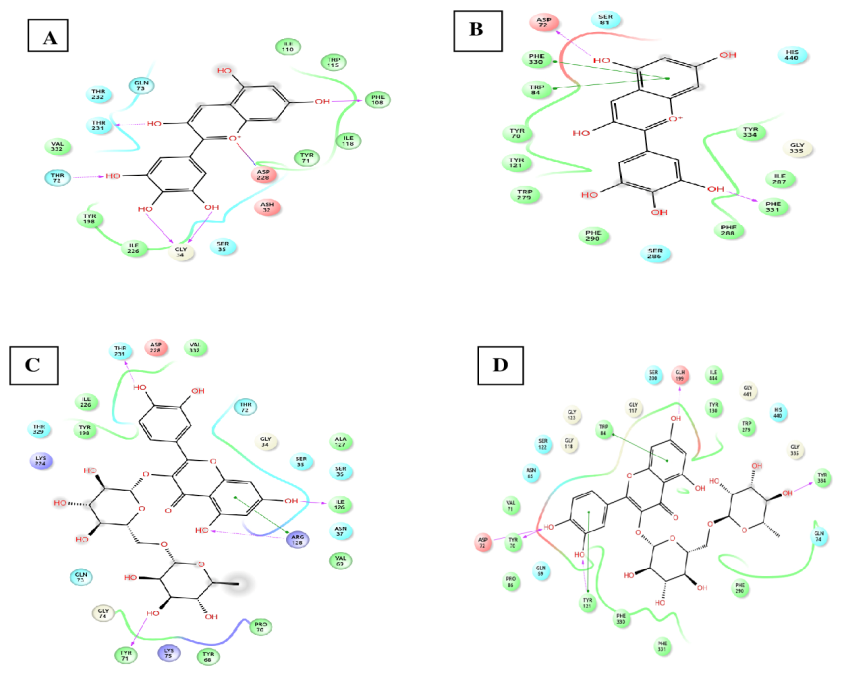

A \& B represents the interaction of Delphinidin component of banana peel extract with Betasecretase $(1 \mathrm{FKN})$ and Acetylcholinesterase (1QTI) consequently. C \& D represents the interaction of rutin component of papaya peel extract with Beta-secretase (1FKN) and Acetylcholinesterase (1QTI) consequently.

Figure 1: Binding pose of Targeted molecules of Ethanolic extract of Bannana and Papaya peel extracts with Beta-secretase and Acetyl cholinesterase.

respectively. Among reported chemical constituents, Delphinidin from banana peel and Rutin Papaya peel exhibit highest docking energy towards Beta-secretase (1FKN) and Acetylcholinesterase (1QTI). From in silico analysis we predicted the mechanism and phytochemicals responsible for anti- neurodegenration effect of banana and papaya peels extract. It is also positively evidenced with in vivo screening with $\mathrm{AlCl}_{3}$ induced memory loss. Spatial navigation deficits are the early hallmark of Alzheimer's disease before full clinical evident and is associated with neurodegeneration of cholinergic neurons in the hippocampus. ${ }^{17}$ Retention of spatial working memory by extract (banana and papaya) is evident by shortening the transfer the latency compared with aluminum chloride prolonged transfer latency time (in a sec). ${ }^{18}$ Which means the extract may have a neuroprotective effect on cholinergic neurons. The Cooks pole climbing apparatus is widely used to assess the ability of an animal to acquire, retention and retrieve the memory process and which was indicated by increasing number of avoidance response. Which means
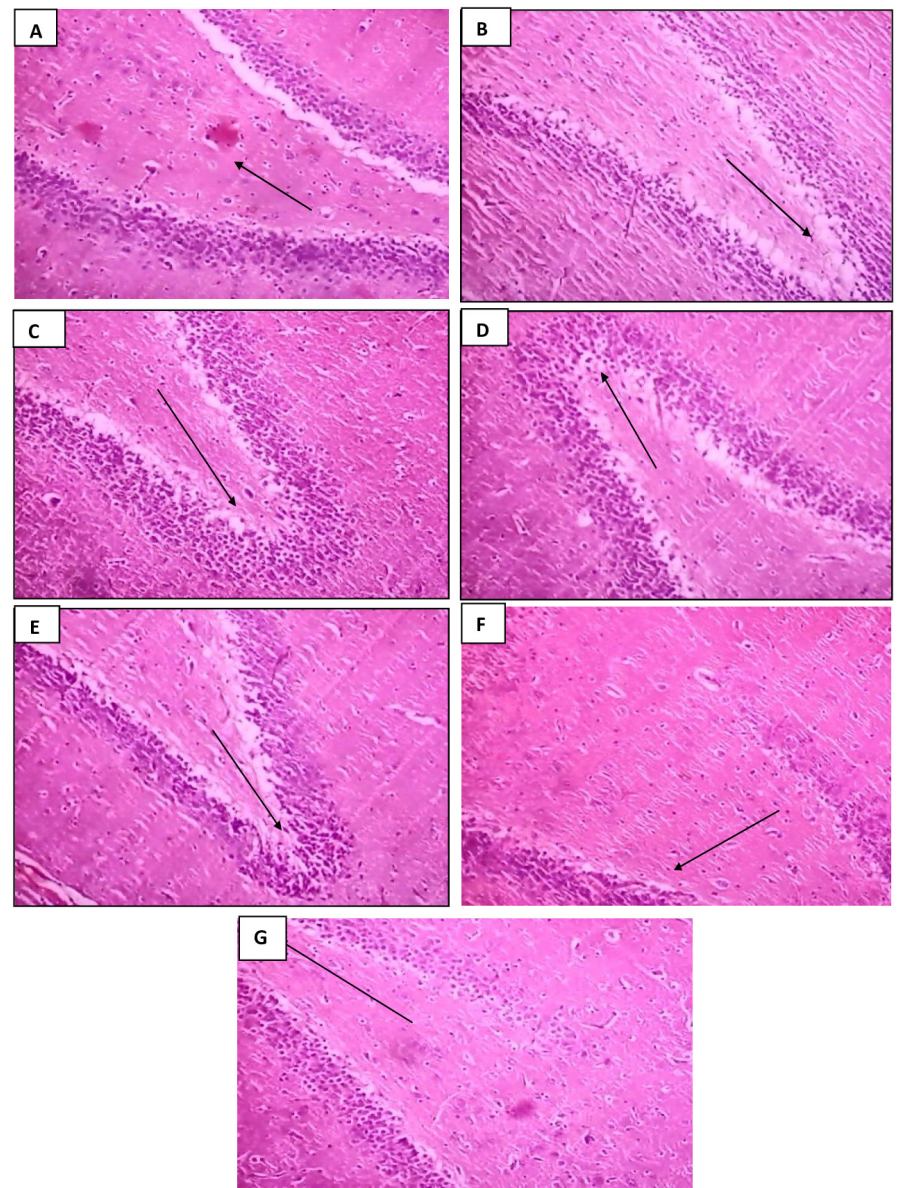

Figure 2: Histopathology of hippocampus. a) Normal control; b) Disease control ( $\left.\mathrm{AlCl}_{3}\right)$; c) Donepezil $1 \mathrm{mg} / \mathrm{kg}$; d) EBP $200 \mathrm{mg} / \mathrm{kg}$; e) EBP $400 \mathrm{mg} / \mathrm{kg}$; f) EPP $200 \mathrm{mg} / \mathrm{kg} ; \mathrm{g}$ ) EPP $400 \mathrm{mg} / \mathrm{kg}$

ability of memory retrieval capacity is also retained by peel extracts. ${ }^{19}$ Weakening of defensive capacity of SOD, CAT, GSH and oxidation of lipid membrane of neurons are destructive events caused by aluminium. ${ }^{20}$ Restoration of the levels of SOD, CAT, GSH and decreased MDA in rat brain by peel extract correlated with the in vitro antioxidant activity of peel extract. The balance of reactive oxygen species and defensive 
factors by natural agents could be proved as better anti-dementia agents. Alzheimer's results from insufficient secretion of acetylcholine and over expression of acetylcholine esterase is a link with a memory deficit. Acetylcholine esterase is more sensitive to environmental factors such as diet. ${ }^{21}$ and metals such as aluminum. Aluminum increases the activity of acetylcholine esterase by altering the secondary structure and thereby more number of acetylcholine molecules are degraded and so acetylcholine-mediated memory process was decline. Banana and papaya pee extract pre-treatment exhibited with significant decline the activity of acetyl cholinesterase. It is a positive correlation with memory enhancement, which is correlated with previous studies. ${ }^{22}$

\section{CONCLUSION}

The results of the present study showed that ethanolic extract of banana and papaya peel extract has dose-dependent neuroprotective and memory enhancing effects, which was revealed by improvement of biochemical, neurobehavioral and histopathological changes. Memory enhancing effects of banana and peel extract were predicted by docking of major leads of extract with acetyl cholinesterase and beta secretase proteins. Delphinidin from banana peel and rutin from papaya peel exhibit extremely good docking score compared to other bioactive molecules such as quercetin, gallocatechin and cyanidin (banana peel) and gallic acid, caffeic acid, isorhamnetin and ferulic acid (papaya peel). Based on these results, we concluded that both peel extract considered as good sources of bioactive molecules fight against memory loss by Alzheimer's disease. Further studies need to be done to explore the activity of active constituents on neuronal cells.

\section{ACKNOWLEDGEMENT}

The authors are very grateful to the Principal and Management of Raghavendra Institute of Pharmaceutical Education and Research (RIPER), Ananthapuramu, Andhra Pradesh, India. We are also thankful to DST-SERB/DST-FIST for Docking facility in molecular modelling and drug discovery division, REDS-CPR, RIPER Campus- Ananthapuramu, Andhra Pradesh, India.

\section{CONFLICT OF INTEREST}

The authors declare no conflict of interest

\section{ABBREVIATIONS}

AD: Alzheimer's disease; NIH: National Institute of Health; $\mathbf{A l C l}_{3}$ : Aluminum chloride; EBP: Ethanolic Banana peel; EPP: Ethanolic Papaya peel; TLC: Thin layer chromatography; GAE: Gallic acid equivalents; QE: Quercetin equivalents; DW: Dry weight; DPPH: 2,2-diphenyl-1picrylhydrazyl; IC $_{50}$ : Inhibitory concentration; PDB: Protein data bank; OECD: Organization for Economic Co-operation and Development; GSH: Reduced glutathione; MDA: Malondialdehyde; PHE: Phenyl alanine; GLY: Glycine; THR: Threonine; ASP: Aspartic acid; TRP: Tryptophan; ARG: Arginine; ILE: Isoleucine; GLH: Glutamic acid; TYR: Tyrosine.

\section{REFERENCES}

1. Brambilla D. Drug discovery, development and delivery in Alzheimer's disease. Pharm Res. 2017;35(1):3.

2. Du X, Wang $X$, Geng M. Alzheimer's disease hypothesis and related therapies. Transl Neurodegener. 2018;7(1):2.

3. Tewari D, Stankiewicz AM, Mocan A, Sah AN, Tzvetkov NT, Huminiecki L, et al. Ethnopharmacological Approaches for Dementia Therapy and Significance of Natural Products and Herbal Drugs. Front Aging Neurosci. 2018;10:3.

4. Cooper EL, Ma MJ. Alzheimer Disease: Clues from traditional and complementary medicine. J Tradit Complement Med. 2017;7(4):380-5.

5. Venkatesan R, Ji E, Kim SY. Phytochemicals That Regulate Neurodegenerative Disease by Targeting Neurotrophins: A Comprehensive Review. Bio Med Res Int. 2015;2015:1-22.

6. Siddique S, Nawaz S, Muhammad F, Akhtar B, Aslam B. Phytochemical screening and in-vitro evaluation of pharmacological activities of peels of Musa sapientum and Carica papaya fruit. Nat Prod Res. 2018;32(11):1333-6.

7. Kumar SM, Upadhyaya K, Rishishwar P. Qualitative and Quantitative Phytochemical Analysis and in-vitro Antioxidant Activity of Caesalpinia bonduc (L.) Seeds. J Biol Act Prod Nat. 2015;5(3):214-22.

8. Siddhuraju P, Becker K. Antioxidant properties of various solvent extracts of total phenolic constituents from three different agroclimatic origins of drumstick tree (Moringa oleifera Lam.) leaves. J Agric Food Chem. 2003;51(8):2144-55.

9. Khalid S, Zahid MA, Ali H, Kim YS, Khan S. Biaryl scaffold-focused virtual screening for anti-aggregatory and neuroprotective effects in Alzheimer's disease. BMC Neurosci. 2018;19(1):74

10. Dhanabal S, Vadivelan R, Maithili V, Mahendran S. Antidiabetic activity of ethanolic extract of tubers of Dioscorea alata in alloxan induced diabetic rats. Indian J Pharmacol. 2011;43(4):455.

11. Lakshmi BVS, Sudhakar M, Prakash KS. Protective effect of selenium against aluminum chloride-induced Alzheimer's disease: Behavioral and biochemical alterations in rats. Biol Trace Elem Res. 2015;165(1):67-74.

12. Kandikattu HK, Deep SN, Razack S, Amruta N, Prasad D, Khanum F. Hypoxia induced cognitive impairment modulating activity of Cyperus rotundus. Physiol Behav. 2017;175:56-65.

13. Mutlu O, Akar F, Celikyurt IK, Tanyeri P, Ulak G, Erden F. 7-NI and ODQ Disturbs Memory in the Elevated Plus Maze, Morris Water Maze and Radial Arm Maze Tests in Mice. Drug Target Insights. 2015;9:1-8.

14. Arya DS, Arora S, Malik S, Nepal S, Kumari S, Ojha S. Effect of Piper betle on cardiac function, marker enzymes and oxidative stress in isoproterenol-induced cardiotoxicity in rats. Toxicol Mech Methods. 2010;20(9):564-71.

15. Ellman GL, Courtney KD, Andres V, Feather-Stone RM. A new and rapid colorimetric determination of acetylcholinesterase activity. Biochem Pharmacol. $1961 ; 7: 88-95$

16. M'rad I, Jeljeli M, Rihane N, Hilber P, Sakly M, Amara S. Aluminium oxide nanoparticles compromise spatial learning and memory performance in rats. EXCLI J. 2018;17:200-10.

17. Vlček K, Laczó J. Neural correlates of spatial navigation changes in mild cog nitive impairment and Alzheimer's disease. Front Behav Neurosci. 2014;8:89.

18. Reddy DS, Kulkarni SK. Possible role of nitric oxide in the nootropic and antiamnesic effects of neurosteroids on aging- and dizocilpine-induced learning impairment. Brain Res. 1998;799(2):215-29.

19. Schimidt HL, Vieira A, Altermann C, Martins A, Sosa P, Santos FW, et al. Memory deficits and oxidative stress in cerebral ischemia-reperfusion: Neuroprotective role of physical exercise and green tea supplementation. Neurobiol Learn Mem. 2014;114:242-50.

20. Majumdar AS, Nirwane A, Kamble R. Coenzyme q10 abrogated the 28 days aluminium chloride induced oxidative changes in rat cerebral cortex. Toxicol Int. 2014;21(2):214-21.

21. Kaizer RR, DaSilva AC, Morsch VM, Corrêa MC, Schetinger MRC. Diet-induced changes in AChE activity after long-term exposure. Neurochem Res. 2004;29(12):2251-5

22. Justin TA, Raja TRW, Janakiraman U, Manivasagam T. Neuroprotective effect of hesperidin on aluminium chloride induced Alzheimer's disease in Wistar rats. Neurochem Res. 2015;40(4):767-76.

Article History: Submission Date : 08-01-2020; Revised Date : 12-02-2020; Acceptance Date : 24-03-2020.

Cite this article: Reddy KS, Likithasree P, Peraman R, Jyothi MV, Babu CN, Pradeepkumar B, Sudheer A. Spatial Long-Term Memory Retention by Banana and

Papaya Peel Extract: In silico and in vivo Evaluation. Int. J. Pharm. Investigation. 2020;10(2):201-7. 